\title{
Nuclear anomalies in the buccal cells of calcite factory workers
}

\author{
Songül Budak Diler ${ }^{1}$ and Serap Ergene ${ }^{2}$ \\ ${ }^{1}$ University of Nigde, Science and Letters, Nigde, Turkey. \\ ${ }^{2}$ University of Mersin, Science and Letters, Mersin, Turkey.
}

\begin{abstract}
The micronucleus (MN) assay on exfoliated buccal cells is a useful and minimally invasive method for monitoring genetic damage in humans. To determine the genotoxic effects of calcite dust that forms during processing, $\mathrm{MN}$ assay was carried out in exfoliated buccal cells of 50 ( 25 smokers and 25 non-smokers) calcite factory workers and 50 (25 smokers and 25 non-smokers) age- and sex-matched control subjects. Frequencies of nuclear abnormalities (NA) other than micronuclei, such as binucleates, karyorrhexis, karyolysis and 'broken eggs', were also evaluated. Micronuclei and the other aforementioned anomalies were analysed by two way analysis of covariance. The linear correlations between the types of micronucleus and nuclear abnormalities were determined by Spearman's Rho. There was a positive correlation between micronuclei and other types of nuclear abnormalities in accordance with the Spearman's Rho test. Results showed statistically significant difference between calcite fabric workers and control groups. MN and NA frequencies in calcite fabric workers were significantly higher than those in control groups $(p<0.05)$. The results of this study indicate that calcite fabric workers are under risk of significant cytogenetic damage.
\end{abstract}

Key words: calcite, exfoliated buccal cells, micronucleus (MN), genotoxicity.

Received: May 4, 2009; Accepted: October 14, 2009.

The chemical formula of calcite that forms limestone is $\mathrm{CaCO}_{3}$ (Cotton and Wilkinson, 1988). Generally it does not exist in pure form in nature. It forms a complex with other chemicals $\left(\mathrm{SiO}_{2}, \mathrm{Al}_{2} \mathrm{O}_{3}, \mathrm{FeO}_{3}, \mathrm{CaO}, \mathrm{MgO}, \mathrm{SO}_{3}\right.$, $\mathrm{Na}_{2} \mathrm{O}, \mathrm{K}_{2} \mathrm{O}, \mathrm{CO}_{2}, \mathrm{Fe}_{2}^{+}$(Goldsmith et al., 1962; Jeong and Youngsin, 2006).

In Turkey, limestone (deposits) reserves have a high percentage of $\mathrm{CaCO}_{3}(96.8 \%$ max.) together with other substances, such as $\mathrm{MgCO}_{3}\left(1 \%\right.$ max), $\mathrm{Fe}_{2} \mathrm{O}_{3}(0.3 \%$ max), acid non-soluble material $(0.02 \% \max )$ and water $(0.4 \%$ max). The amount of silica and impurities from iron compounds are very low (Böke et al., 1999; Dilsiz, 2002).

After being ground into a fine powder, calcite is widely used in industry for making paint, paper and plastic adhesives, as well as a filling substance in food, chemical and construction products (Yekeler and Ozkan, 2002).

The harmful effects of mineral dust in various forms on human health have already been demonstrated (Guthrie, 1992; Dong et al., 2006; Prince et al., 2008), notably the dust from iron ore was found to be toxic by genotoxicity tests (Dönbak et al., 2005). In addition, the dust of the calcite mineral was found to cause lung damage (Jaunarajs and Liebling, 1972; Zhang and Huang, 2005; Erren et al., 2007). On investigating the genotoxic effects of environmental factors on human nuclei, the micronucleus (MN)

Send correspondence to Songül Budak Diler. University of Nigde, Science and Letters, 51200 Nigde, Turkey. E-mail: budakdiler@gmail.com. test has been employed on buccal epithelial cells (Sarto et al., 1987; Tolbert et al., 1992; Levine et al., 1997), The MN test, which is scientifically approved, is important in demonstrating the genotoxic effects of harmful substances on human health (Nersesyan, 2005; Nersesyan et al., 2006; Fenech et al., 2007), such as in measuring genotoxicity in petrol station employees (Çelik et al., 2003; Benites et al., 2006), agricultural workers (Pastor et al., 2001), cigarette smokers and tobacco users (Özkul et al., 1997; Besaratinia et al., 2000; Proia et al., 2006). In addition, it has been used in workers exposed to pesticides (Pastor et al., 2002), polycyclic aromatic hydrocarbons (Karahalil et al., 1999), timber dust (Çelik and Kanik, 2006), ozone and cancer patients (Bloching et al., 2000; Chen et al., 2006).

The aim of our study was to determine the effects of calcite dust formed during its processing on the health of employees of calcite factories by employing the $\mathrm{MN}$ test on buccal epithelial cells, which has not been performed so far in any other study in this context.

The study was carried out with 50 calcite factoryworkers, ( 25 smokers and 25 non-smokers) working in the town of Nigde. The control group consisted of 50 healthy men (25 smokers and 25 non-smokers) working on the Nigde University campus, with no known previous occupational exposure to genotoxic substances. The questionnaire covered standard demographic (age, gender, etc.), lifestyle (smoking, alcohol consumption, etc.) and occupational (working hours/day, period of exposure, etc.) as- 
pects. There were no significant differences as regards lifestyle and personal factors in participants of the study groups.

Buccal cell samples were collected at the end of work-shifts. Subjects were required to rinse their mouths with water before sampling. Exfoliated epithelial cells of buccal mucosa were obtained by scraping the middle part of the inner cheek with a wooden spatula. The epithelial cells collected from buccal mucosa were smeared onto clean microscope glass slides. The slides were air-dried and fixed with cold $100 \%$ methanol. The slides were incubated at $37^{\circ} \mathrm{C}$ overnight and then stained with Giemsa (Stich and Rosin, 1984; Acar et al., 2001).

A light microscope using $100 \mathrm{X}$ magnification on coded slides was used for MN analysis. Four replicate slides were prepared for each subject and 1000 cells evaluated per slide to determine $\mathrm{MN}$ frequency. Thus, at least 4000 cells per person were scored for every four slides.

$\mathrm{MN}$ and other nuclear abnormalities were classified according to Tolbert et al. (1992). MNs must satisfy the following conditions: a) consist of nuclear material; b) be completely separated from the parent nucleus; c) be less than $1 / 3$ of the diameter of associated nuclei; d) be smooth, oval- or round-shaped; e) be on the same plane of focus and f) be of the same color, texture and refraction as the main nucleus. Cells with two nuclei were considered to be binucleate. Besides $\mathrm{MN}$, other nuclear anomalies, such as karyorrhexis (nuclear disintegration), karyolysis (dissolution of nucleus) and 'broken eggs' (nuclei that appeared cinched) were recorded separately according to Tolbert $e t$ al. (1991).

The statistical analyses were performed using the SPSS software, version 11.5 (SPSS, Chicago,IL). All the data were expressed as the mean \pm standard error of the mean. MNs and other nuclear abnormalities (binucleates, karyorrhexis, karyolysis and 'broken eggs') were analysed by two way analysis of covariance in workers and smokers in order to delineate possible differences between these two groups. In all analyses, the age variable was include in the calculations as a covariant. Linear correlations of the various types of MN and nuclear abnormalities were determined by Spearman's Rho. The SPSS v11.5 programme package was used for statistical analysis. Results with $\mathrm{p}<0,05$ were considered significant.

A summary of dermographic characteristics of the groups studied appear in Table 1. 25 of the 50 members $(50 \%)$ of both the study and control groups were smokers. As described in materials and methods, buccal epithelial samples were obtained from all the 100 involved subjects. 4000 cells from each were evaluated for micronuclei and other nuclear abnormalities (binucleates (BN), karyorrhexis (KR), karyolysis (KL), 'broken eggs' (BE)), counted and statistically analyzed using SPSS. MN and the other anomalies were appraised through two way analysis of covariance in workers and smokers in order to delineate possible differences between the two groups. Differences in age were not statistically significant $(p>0.05)$. In terms of duration of work the difference between smokers and non-smokers was also not significant $(\mathrm{p}>0.05)$ (Table 1). With respect to $\mathrm{BE}$, the interaction for working and smoking was significant $(\mathrm{p}<0.05)$, whereas the opposite was true for $\mathrm{MN}, \mathrm{BN}, \mathrm{KR}$ and $\mathrm{KL}(\mathrm{p}>0.05)$ (Table 2). For MN, $\mathrm{BN}$ and $\mathrm{BE}$, there was a significant difference $(\mathrm{p}<0.05)$ between smokers and non-smokers, whereas the opposite was the case for KR and KL ( $p>0.05)$. There was also a significant difference between exposed workers and control groups as regards $\mathrm{MN}, \mathrm{BN}, \mathrm{BE}, \mathrm{KR}$ and $\mathrm{KL}(\mathrm{p}<0.05)(\mathrm{Ta}-$ ble 3). Furthermore, according to Spearman's Rho testing, the correlations between $\mathrm{MN}$ and other types of nuclear abnormalities were positive (Table 4).

The MN test is a very useful and efficient method for specifying buccal epithelial cell chromosomal abnormalities (Levine et al., 1997; Holland et al., 2008). Although studies on the genotoxicity of calcite mineral dust are very limited, the effect of this exposure on the lungs has been investigated more extensively and it was found to be damaging (Seldén et al., 2001; Dogan, 2003; Özkurt et al., 2003). At the same time it has been shown that some mineral dusts are factors in lung cancer risk (Wendlandt et al., 2007; Dogan et al., 2008).

The factor 'smoking' was also taken into account, whereby it was found that nuclear abnormalities were higher in smokers, and previous studies in this regard confirm our findings (Özkul et al., 1997; Proia et al., 2006). Other investigators used the buccal MN test and demon-

Table 1 - General characteristics of the groups studied.

\begin{tabular}{lllccc}
\hline Study group & & $\mathrm{n}$ & Age (years) & Average no of cigarettes/day & Duration of employment (years) \\
\hline Control & Smokers & 25 & $29.00 \pm 1.76$ & 23 & \\
& Non-smokers & 25 & $32.36 \pm 1.85$ & 23 & $3.24 \pm 0.44$ \\
\multirow{5}{*}{ Workers } & Total & 50 & $30.68 \pm 1.28$ & 18 & $4.00 \pm 0.69$ \\
& Smokers & 25 & $29.84 \pm 1.06$ & & $3.62 \pm 0.40$ \\
\hline
\end{tabular}


Table 2 - The frequencies (\%) of micronuclei and other nuclear abnormalities in exfoliated buccal epithelial cells of control and exposed subjects.

\begin{tabular}{|c|c|c|c|c|c|c|c|}
\hline \multirow[t]{2}{*}{ Group } & & \multirow[t]{2}{*}{$\mathrm{n}$} & \multirow{2}{*}{$\begin{array}{c}\text { Micronuclei } \\
\text { mean (a) } \pm \mathrm{SE}\end{array}$} & \multicolumn{4}{|c|}{ Nuclear abnormality } \\
\hline & & & & $\begin{array}{c}\text { Binucleates } \\
\text { mean (a) } \pm \mathrm{SE}\end{array}$ & $\begin{array}{l}\text { Broken eggs } \\
\text { mean (a) } \pm \mathrm{SE}\end{array}$ & $\begin{array}{l}\text { Karyorrhexis } \\
\text { mean (a) } \pm \mathrm{SE}\end{array}$ & $\begin{array}{c}\text { Karyolysis } \\
\text { mean (a) } \pm \mathrm{SE}\end{array}$ \\
\hline \multirow[t]{2}{*}{ Control } & Smokers & 25 & $11.41 \pm 1.12$ & $4.75 \pm 0.88$ & $3.52 \pm 1.51$ & $1.10 \pm 0.25$ & $1.23 \pm 0.43$ \\
\hline & Non-smokers & 25 & $4.68 \pm 1.11$ & $3.42 \pm 0.88$ & $5.21 \pm 1.51$ & $1.05 \pm 0.25$ & $1.31 \pm 0.43$ \\
\hline \multirow[t]{2}{*}{ Workers } & Smokers & 25 & $25.52 \pm 1.11$ & $11.28 \pm 0.87$ & $15.16 \pm 1.50$ & $3.05 \pm 0.25$ & $1.90 \pm 0.43$ \\
\hline & Non-smokers & 25 & $15.19 \pm 1.11$ & $6.98 \pm 0.87$ & $4.09 \pm 1.50$ & $2.27 \pm 0.25$ & $3.10 \pm 0.43$ \\
\hline
\end{tabular}

(a): Covariates appearing in the model are evaluated at the following values: Age $=30,9400$.

Table 3 - The mean effect (\%) of micronuclei and other nuclear abnormalities in exfoliated buccal epithelial cells of subjects from control groups, exposed workers, smokers and non-smokers.

\begin{tabular}{|c|c|c|c|c|c|c|}
\hline \multirow[t]{2}{*}{ Group } & \multirow[t]{2}{*}{$\mathrm{n}$} & \multirow{2}{*}{$\begin{array}{c}\text { Micronuclei } \\
\text { mean (a) } \pm \mathrm{SE}\end{array}$} & \multicolumn{4}{|c|}{ Nuclear abnormality } \\
\hline & & & $\begin{array}{l}\text { Binucleates } \\
\text { mean (a) } \pm \text { SE }\end{array}$ & $\begin{array}{l}\text { Broken eggs } \\
\text { mean (a) } \pm \mathrm{SE}\end{array}$ & $\begin{array}{l}\text { Karyorrhexis } \\
\text { mean (a) } \pm \mathrm{SE}\end{array}$ & $\begin{array}{c}\text { Karyolysis } \\
\text { mean (a) } \pm \mathrm{SE}\end{array}$ \\
\hline Control & 50 & $8.04 \pm 0.78$ & $4.08 \pm 0.61$ & $4.37 \pm 1.06$ & $1.07 \pm 0.17$ & $1.27 \pm 0.30$ \\
\hline Workers & 50 & $20.36 \pm 0.78$ & $9.13 \pm 0.61$ & $9.62 \pm 1.06$ & $2.66 \pm 0.17$ & $3.50 \pm 0.30$ \\
\hline Smokers & 50 & $18.47 \pm 0.78$ & $8.01 \pm 0.61$ & $10.19 \pm 1.06$ & $2.07 \pm 0.17$ & $2.57 \pm 0.30$ \\
\hline Non-smokers & 50 & $9.93 \pm 0.78$ & $5.20 \pm 0.61$ & $3.81 \pm 1.06$ & $1.66 \pm 0.17$ & $2.20 \pm 0.30$ \\
\hline
\end{tabular}

(a): Covariates appearing in the model are evaluated at the following values: Age $=30,9400$.

Table 4 - The correlation coefficient between MNs and different types of cytogenetic endpoints.

\begin{tabular}{|c|c|c|c|c|c|c|}
\hline & & MN & $\mathrm{BN}$ & $\mathrm{BE}$ & KL & $\mathrm{KR}$ \\
\hline \multirow[t]{3}{*}{ MN } & Correlation Coefficient & & $0.643(* *)$ & $0.417(* *)$ & $0.528(* *)$ & $0.588(* *)$ \\
\hline & Sig. (2-tailed) & & 0.000 & 0.000 & 0.000 & 0.000 \\
\hline & $\mathrm{N}$ & & 100 & 100 & 100 & 100 \\
\hline \multirow[t]{3}{*}{$\mathrm{BN}$} & Correlation Coefficient & $0.643(* *)$ & & $0.624(* *)$ & $0.516(* *)$ & $0.615(* *)$ \\
\hline & Sig. (2-tailed) & 0.000 & & 0.000 & 0.000 & 0.000 \\
\hline & $\mathrm{N}$ & 100 & & 100 & 100 & 100 \\
\hline \multirow[t]{3}{*}{$\mathrm{BE}$} & Correlation Coefficient & $0.417(* *)$ & $0.624(* *)$ & & $0.218\left(^{*}\right)$ & $0.402(* *)$ \\
\hline & Sig. (2-tailed) & 0.000 & 0.000 & & 0.030 & 0.000 \\
\hline & $\mathrm{N}$ & 100 & 100 & & 100 & 100 \\
\hline \multirow[t]{3}{*}{$\mathrm{KL}$} & Correlation Coefficient & $0.528(* *)$ & $0.516(* *)$ & $0.218(*)$ & & $0.688(* *)$ \\
\hline & Sig. (2-tailed) & 0.000 & 0.000 & 0.030 & & 0.000 \\
\hline & $\mathrm{N}$ & 100 & 100 & 100 & & 100 \\
\hline \multirow[t]{3}{*}{$\mathrm{KR}$} & Correlation Coefficient & $0.588(* *)$ & $0.615(* *)$ & $0.402(* *)$ & $0.688(* *)$ & \\
\hline & Sig. (2-tailed) & 0.000 & 0.000 & 0.000 & 0.000 & \\
\hline & $\mathrm{N}$ & 100 & 100 & 100 & 100 & \\
\hline
\end{tabular}

** Correlation is significant at the 0.01 level (2-tailed).

* Correlation is significant at the 0.05 level (2-tailed).

strated that there was an increase in the incidence of nuclear abnormalities in alcohol consumers and workers exposed to environmental pollutants (Ramirez and Saldanha, 2002; Reis et al., 2006). Furthermore, on using the same assay in measuring micronuclei and nuclear abnormalities in timber workers exposed to wood dust, the difference between these and control subjects was found to be statistically significant (Çelik and Kanik, 2006). Similar genotoxic studies in coal mine workers demonstrated that the incidence of nuclear anomalies, including sister chromatid exchanges 
(SCEs) and chromosomal aberrations (CAs), in those exposed to coal dust, was higher than in controls (Dönbak et al., 2005).

Our study too shows that there is an increase in MN and nuclear abnormalities in workers exposed to calcite dust when compared to on-exposed controls.

\section{Acknowledgments}

This work was supported by the Research Found of Nigde University (Project No. FEB 2007/09).

\section{References}

Acar H, Caliskan U, Demirel S and Largaespada DA (2001) Micronucleus incidence and their chromosomal origin related to therapy in acute lymphoblastic leukemia (ALL) patients: Detection by micronucleus and FISH techniques. Teratogen Carcinogen Mutagen 21:341-347.

Benites CI, Amado LL, Vianna RAP and Martino-Roth MG (2006) Micronucleus test on gas station attendants. Genet Mol Res 5:45-54.

Besaratinia A, Van Straaten HW, Godschalk RW, Van Zandwijk N, Balm AJ, Kleinjans JC and Van Schooten FJ (2000) Immunoperoxidase detection of polycyclic aromatic hydrocarbon -DNA adducts in mouth floor and buccal mucosa cells of smokers and nonsmokers. Environ Mol Mutagen 36:127-133.

Bloching M, Hofmann A, Lautenschlager C, Berghaus A and Grummt T (2000) Exfoliative cytology of normal buccal mucosa to predict the relative risk of cancer in the upper aerodigestive tract using the MN-assay. Oral Oncol 36:550-555.

Böke H, Göktürk EH, Caner-Saltik EN and Demirci S (1999) Effect of airborne particle on SO2-calcite reaction. Appl Surface Sci 140:70-82.

Chen C, Arjomandi A, Qin H, Balmes J, Tager I and Holland N (2006) Cytogenetic damage in buccal epithelia and peripheral lymphocytes of young healthy individuals exposed to ozone. Mutagenesis 21:131-137.

Cotton FA and Wilkinson G (1988) Advanced Inorganic Chemistry. Wiley \& Sons, New York, 1455 pp.

Çelik A, Çava T and Ergene-Gözükara S (2003) Cytogenetic biomonitoring in petrol station attendants: Micronucleus test in exfoliated buccal cells. Mutagenesis 18:417-421.

Çelik A and Kanik A (2006) Genotoxicity of occupational exposure to wood dust: Micronucleus frequency and nuclear changes in exfoliated buccal mucosa cells. Environ Mol Mutagen 47:693-698.

Dilsiz C (2002) Environmental issues concerning natural resources at Pamukkale protected site, southwest Turkey. Environ Geol 41:776-784.

Dogan AU, Dogan M and Hoskins JA (2008) Erionite series minerals: Mineralogical and carcinogenic properties. Environ Geochem Health 30:367-381.

Dogan M (2003) Sources and types of mineral dust in regions of Turkey with endemic malignant mesothelioma. Indoor Built Environ 12:377-383.

Dong F, Deng J, Pu X and John H (2006) Pulmonary alveolar macrophage cytotoxicity investigation of irregular shape mineral dusts. Sheng Wu Yi Xue Gong Cheng Xue Za Zhi 23 848-51.

Dönbak L, Rencuzogullari E, Yavuz A and Topaktas M (2005) The genotoxic risk of underground coal miners from Turkey. Genet Toxicol Environ Mutagen 588:82-87.

Erren TC, Morfeld P, Glende CB and Piekarski C (2007) Silica and lung cancer. Epidemiology 18:521-522.

Fenech M, Bolognesi C, Kirsch-Volders M, Bonassi S, Zeiger E, Knasmüller S and Holland N (2007) Harmonisation of the micronucleus assay in human buccal cells - A Human Micronucleus (HUMN) project (www.humn.org) initiative commencing in 2007. Mutagenesis 22:3-4.

Guthrie Jr GD (1992) Biological effects of inhaled minerals. Am Mineral 77:225-243.

Goldsmith JR, Graf DL and Witters JDA (1962) Northrop Studies in the system $\mathrm{CaCO} 3 \cdot \mathrm{MgCO} 3 \cdot \mathrm{FeCO} 3$ : (1) Phase relations; (2) A method for major element spectrochemical analyses; and (3) Composition of some ferroan dolomites. J Geol 70:659-688.

Holland N, Bolognesi C, Kirsch-Volders M, Bonassi S, Zeiger E, Knasmueller S and Fenech M (2008) The micronucleus assay in human buccal cells as a tool for biomonitoring DNA damage: The HUMN project perspective on current status and knowledge gaps. Mutat Res 659:93-108.

Jaunarajs KL and Liebling RS (1972) The digestion of lung tissue for mineral dust recovery. Am Indust Hygiene Assoc J 33:535-542.

Jeong GY and Youngsin C (2006) Nanofiber calcite in Asian dust and its atmospheric roles. Geophys Res Lett 33:L24802.

Karahalil B, Karakaya AE and Burgaz S (1999) The micronucleus assay in exfoliated buccal cells: Application to occupational exposure to polycyclic aromatic hydrocarbons. Genet Toxicol Environ Mutagen 442:29-35.

Levine AJ, Savlan A, Talaksa G, Boeniger MF, Suruda A and Schulte PA (1997) The utility of epithelial-cell micronuclei in the assessment of intermittent exposures. Biomarkers 2:135-138.

Nersesyan AK (2005) Nuclear buds in exfoliated human cells. Genet Toxicol Environ Mutagen 88:64-68.

Nersesyan AK, Kundi M, Atefie K, Schulte-Hermann R and Knasmüller S (2006) Effect of staining procedures on the results of micronucleus assays with exfoliated oral mucosa cells. Cancer Epidem Biomar 15:1835-1840.

Özkul Y, Donmez H, Erenmemisoglu A, Demirtas H and Imamoglu N (1997) Induction of micronuclei by smokeless tobacco on buccal mucosa cells of habitual users. Mutagenesis 12:285-287.

Özkurt S, Kiter G, Baser S, Arpaz S, Hacioglu M, Fisekci F, Köktürk U and Çimrin HA (2003) The frequency of calcific pleural plaque in Yukaribogaz villagers. Solunum 5:25-29.

Pastor S, Gutiérrez S, Creus A, Xamena N, Piperakis S and Marcos R (2001) Cytogenetic analysis of Greek farmers using the micronucleus assay in peripheral lymphocytes and buccal cells. Mutagenesis 16:539-545.

Pastor S, Creus A, Xamena N, Siffel C and Marcos R (2002) Occupational exposure to pesticides and cytogenetic damage: Results of a Hungarian population study using the micronucleus assay in lymphocytes and buccal cells. Environ Mol Mutagen 40:101-109.

Prince AP, Kleiber PD, Grassian VH and Young MA (2008) Reactive uptake of acetic acid on calcite and nitric acid reacted 
calcite aerosol in an environmental reaction chamber. Phys Chem Chem Phys 10:142-152.

Proia NK, Paszkiewicz GM, Nasca MSS, Franke GE and Pauly JL (2006) Smoking and smokeless tobacco-associated human buccal cell mutations and their association with oral cancer A review. Cancer Epidemiol Biomarkers Prevent 15:10611077.

Ramirez A and Saldanha PH (2002) Micronucleus investigation of alcoholic patients with oral carcinomas. Genet Mol Res 1:246-260.

Reis SRA, Santo ARE, Andrade MGS and Sadigursky M (2006) Cytologic alterations in the oral mucosa after chronic exposure to ethanol. Braz Oral Res 20:97-102.

Sarto F, Finotto S, Giacomelli L, Mazzotti D, Tomanin R and Levis AG (1987) The micronucleus assay in exfoliated cells of the human buccal mucosa. Mutagenesis 2:11-17.

Seldén AI, Berg NP, Lundgren EAL, Hillerdal G, Wik NG, Ohlson CG and Bodin LS (2001) Exposure to tremolite asbestos and respiratory health in Swedish dolomite workers. Occup Environ Med 58:670-677.
Stich HF and Rosin MP (1984) Micronuclei in exfoliated human cells as a tool for studies in cancer risk and cancer intervention. Cancer Lett 22:241-53.

Tolbert PE, Shy CM and Allen JW (1991) Micronuclei and other nuclear anomalies in buccal smears: A field test in snuff users. Am J Epidemiol 134:840-850.

Tolbert PE, Shy CM and Allen JW (1992) Micronuclei and other nuclear anomalies in buccal smears: Methods development. Mutat Res 271:69-77.

Yekeler M and Ozkan A (2002) Determination of the breakage and wetting parameters of calcite and their correlations. Part Part Syst Char 19:419-425.

Wendlandt RF, Harrison WJ and Vaughan DJ (2007) Surface coatings on quartz grains in bentonites and their relevance to human health. Appl Geochem 22:2290-2306.

Zhang Q and Huang X (2005) Addition of calcite reduces iron's bioavailability in the Pennsylvania coals - Potential use of calcite for the prevention of coal worker's lung diseases. J Toxicol Environ Health 68:1663-1679.

Associate Editor: Catarina S. Takahashi

License information: This is an open-access article distributed under the terms of the Creative Commons Attribution License, which permits unrestricted use, distribution, and reproduction in any medium, provided the original work is properly cited. 